\title{
Institutional Sustainability Barriers of Community Conservation Agreement as a Collaboration Management in Lore Lindu National Park
}

\author{
Sudirman Daeng Massiri ${ }^{i^{*}}$, Bramasto Nugroho ${ }^{2}$, Hariadi Kartodihardjo ${ }^{2}$, Rinekso Soekmadi ${ }^{3}$
}

\begin{abstract}
${ }^{1}$ Graduate School of Bogor Agricultural University, Dramaga Main Road, Campus IPB Dramaga, Bogor, Indonesia 16680
${ }^{2}$ Department of Forest Management, Faculty of Forestry, Bogor Agricultural University, Academic Ring Road, Campus IPB Dramaga, PO Box 168, Bogor, Indonesia 16680

${ }^{3}$ Departement of Forest Resource Conservation and Ecoturism, Faculty of Forestry, Bogor Agricultural University, Campus IPB Dramaga, Bogor, Indonesia 16680
\end{abstract}

Received June 29, 2015/Accepted November 18, 2015

\begin{abstract}
The main problem of forest institutional arrangement is the issue of institutional sustainability in achieving sustainable forest ecosystem. This study aimed to explain the barriers of institutional sustainability Community Conservation Agreement (CCA) designed in Lore Lindu National Park (LLNP), in Indonesia, as a collaborative management of national parks. This study is of descriptive which used qualitative approach, i.e. asking open-ended questions, reviewing documentation and analyzing textual of community conservation agreements. We found that the institutional sustainability barriers of CCA were the local decisions on collective-choice level and that the rules at operational level arranged in CCA were not in line with formal rules of national park management at the constitutional level. Furthermore, the low capacity of local institutions in heterogeneous villages with many migrants in controlling and regulating the forest use, especially in rehabilitation zone areas, also became a barrier to institutional sustainability of CCA. Therefore, institutional sustainability of CCA requires support of national park management policy that accommodates the sustainability of livelihoods of local communities in national parks, strengthening local institution's capacity, and ultimately integrating institution of CCA as part of LLNP management.
\end{abstract}

Keywords: institution, collaboration, sustainability, CCA, national park

*Correspondence author, email: sudi_untad@yahoo.co.id, ph.: +62-81227153737

\section{Introduction}

National parks protect non-excludable resources that provide goods and services such as biodiversity, landscape beauty and a variety of ecological services that are difficult to be provided through market mechanisms. The state/government should protect and provide non-excludable resources, especially those that are indivisible because the private sector is not interested in providing them, even though the demand for these resources is very high (Nugroho et al. 2012). The characteristic of these resources present a challenge for the state in achieving sustainability.

Management of Lore Lindu National Park (LLNP), located in Central Sulawesi Province, Indonesia, characterized by interdependence between the local communities and the LLNP management driven by the characteristics of the resource including high exclusion costs and incompatible in use (Schmid 2004). These situations need to change the paradigm of national park management, accommodating the local communities' interests, using their traditional knowledge and local wisdom (Soekmadi 2003; Ezebilo 2011; Kosmaryandi et al. 2012; Kitamura \& Clapp 2013). Properly, local communities should not be positioned as a threat, but as the potential to sustain protected areas because they have used forest resources in a long time (Abdullahi \& AbdulHameed 2012).

Appropriate institutional arrangements of forest management enable to use of forests and conservation goals can be achieved (Acheson 2006). Bundle of rights owned by the parties will determine their position to resources (Schlager \& Ostrom 1992), and decide incentive to preserve and conserve the resources (Agrawal \& Ostrom 2001; Agrawal et al. 2013). Property rights also play an important role in the livelihoods of communities who depend on forests and affect forest condition (Lambini \& Nguyen 2014).

Community Conservation Agreements (CCA) in LLNP which was initiated by international NGOs and local NGOs in approximately 40 villages around LLNP in the early 2000s was the forerunner of co-management (Birner \& Mappatoba 
2009). CCAs are considered a promoting tool to mediate between national park conservation interests and local people's needs, integrating traditional informal rules and should consider cultural diversity (Mehring et al. 2011). Ekpe (2012) revealed that the granting of legal rights or collaborative management is a form of incentives for influencing behavior of people to conserve biodiversity. Recognition and incorporation of local institutions are necessary as a solution to the problem of non-excludability and property rights in achieving sustainable forest management (Nursidah et al. 2012).

The critical problem in institutional arrangement is the issue of sustainability (Adiwibowo et al. 2013). Based on our pre study in 2 heterogeneous villages that have many migrants, the institutional arrangement of CCA is not implemented sustainably. The research question of this study is to explain why the institutional arrangement of CCA doesn't work properly as collaboration on LLNP management. The purpose of this study was to explain profoundly institutional barriers of CCA. We assumed that institutional sustainability barriers of CCA not only depend on the situation and structure (Schmid 2004), but also depend on the role of stakeholders in implementing the rules. Capacity stakeholder is a key for the development and institutional change. It illustrates the ability of individuals, groups or organization to respond the environmental change as part of effort in achieving the goal (Dubois 1998).
Capacity of actors would drive their behavior (Ribot \& Peluso 2003). This research applied the framework of Situation, Structure, Behavior, Performance (SSBP) (Schmid 2004), with modification (Figure 1).

\section{Methods}

This research was conducted from June 2014 to January 2015 at LLNP, located in Central Sulawesi Province, Indonesia. This research conducted a qualitative approach (Creswell 2012), namely exploring and understanding the institutional sustainability barriers by asking open-ended questions to key informants, reviewing data of documentation CCA, and analyzing texts rules of national parks management. This research applied snowballing technic to define the key informants. The interview process was started from the staffs of village conservation council (lembaga konservasi desa/LKD), village chiefs, chairmen of customary institutions and local community in 2 homogeneous villages and 2 heterogeneous villages that have many migrants around LLNP that implementing CCA, and 4 people from the buffer zone forum (forum wilayah penyangga/FWP). The kinds of our questions were institutional structure, including property rights of local communities negotiated in CCA, rules, and their capacity in implementing the rules. Furthermore, the interviews were conducted with 2 local non-government organizations (NGOs) that were facilitating the arrangement of CCA by

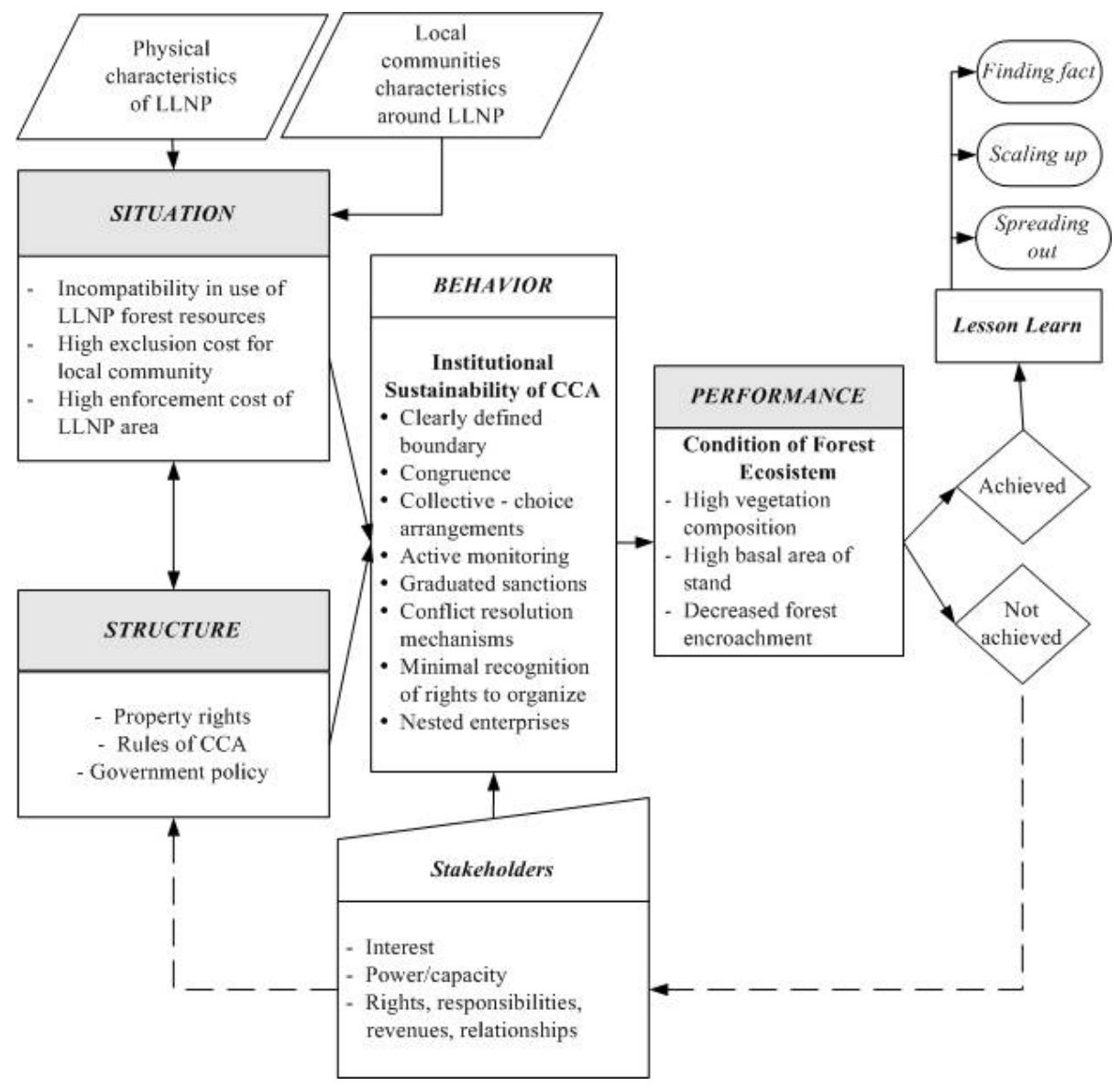

Figure 1 Framework, adapted from Schmid (2004). 
asking the arrangement process of CCA and their capacity in facilitating. The interview process was also conducted with LLNP officers to find out the structure that hampers CCA and with the Regional Development Planning Agency of District Poso and District Sigi to understand their capacity in supporting and strengthening the local institutions.

This research used descriptive analysis (Irawan 2006) to explain profoundly the institutional sustainability barriers of CCA by analyzing the structure of institution CCA and the role of stakeholders. We used the theory of property rights (Schlager \& Ostrom 1992) and theory of rules (Ostrom 1990; Ostrom 2005) to describe the structural barriers of institutional sustainability of CCA. In addition, we used analysis of stakeholders (Dubois 1998) and stakeholders' capacity (Ribot \& Peluso 2003) to describe the barriers in implementing CCA.

\section{Results and Discussion}

Property rights of local community negotiated on CCA Bundle of rights of local communities negotiated on CCA consist of access and withdrawal rights, management rights, and exclusion rights and did not hold alienation rights, but these rights can be bequeathed (Table 1).

Position of local communities in LLNP management, based on bundle of rights designed on CCA, was as proprietor. The proprietors not only hold the rights at operational level, such as access and withdrawal rights, but also hold rights at collective-choice level, such as management and alienation rights (Schlager \& Ostrom 1992). Agrawal and Ostrom (2001) stated that the position as proprietor who holds collective-choice rights can create incentives to conserve resources. Based on document of $\mathrm{CCA}$, local communities allowed to regulate the internal use of resources.

Rules designed in CCA Rules in managing of Common Pool Resource (CPRs) consist of 3 levels, which are rules at operational level, rules at collective-choice level, and rules at constitutional level (Ostrom 1990). Description of rules designed in CCA is shown in Figure 1.
Collective-choice rules These rules adjust how to regulate the aggregation of appropriator and consider their preference in management (Anderies et al. 2004). The aim of these rules is to arrange the operational rules (Ostrom 1990). Arrangement of operational rules of CCA involved several stakeholders specially LKD, village chief, customary institution, LLNP officer and facilitated by NGOs The Natural Conservation (TNC) and local NGOs. Collectivechoice rights of local communities in management of LLNP designed in CCA were delegated to LKD. Operational rules of CCA that were described in the participatory management plan set by LKD and LLNP officer and facilitated by NGOs. However, LLNP officer stated that motions of CCA and participatory management plan was the concept of NGOs who was facilitating and it based on their orientation value.

Operational rules These rules are required to avoid overexploitation of resources (Anderies et al. 2004) and specify what activity allowed or forbidden (Ostrom 2005).

1 Rules of resource utilization in CCAArea

Forest resources of LLNP located in CCA area allowed to meet the local needs of villagers CCA, but not allowed for the outsider. The forest resources allowed to be used consist of non-wood forest products such as rattan, bamboo, palm, medicinal plants, dammar and water resources, and timber for public facilities and the local communities' needs. Villagers also hold rights to manage their gardens existing in the LLNP with the provision that they were forbidden to expand the garden. Withdrawal rules of rattan, bamboo and dammar sap regulated using a rotation system which set out in the participatory management plan. The harvesting procedures of these resources were arranged so that did not damage the trees and wildlife habitat, and local communities should regenerate the harvested resources. Local communities who need forest resources in CCA area should ask permission to LKD. Furthermore, the LKD coordinates with the village chief and customary institution, and they checked the local communities' needs both the number and usefulness of the resource. LKD also should report to

Table 1 Bundle of rights of local community negotiated on CCA in LLNP management

\begin{tabular}{lc}
\hline \multicolumn{1}{c}{ Bundle of Rights } & \multicolumn{1}{c}{ Descriptions } \\
\hline Access rights & Local communities can enter to enjoy the natural beauty in LLNP area. \\
Withdrawal rights & Withdrawal of timber in the CCA area for the purpose of public facilities and \\
& local community needs, not for commercial purposes \\
& - Withdrawal of non-timber forest products such as dammar sap, rattan, bamboo, \\
& pandanus of forest, sugar palm, traditional medicines and water in LLNP area \\
& - Withdrawal of garden product existing in the TNLL area \\
& - Managing continuously the farm existing in LLNP area \\
Management Rights & Regulating the internal utilization of forest resources in CCA area \\
& - Rehabilitating the bare land \\
Exclusion rights & - Controlling the forest area and monitoring forest health \\
& - Exclude unauthorized parties from utilization of forest resources in CCA area \\
Alienation rights & Impose sanctions on parties who violate the agreement \\
\hline
\end{tabular}




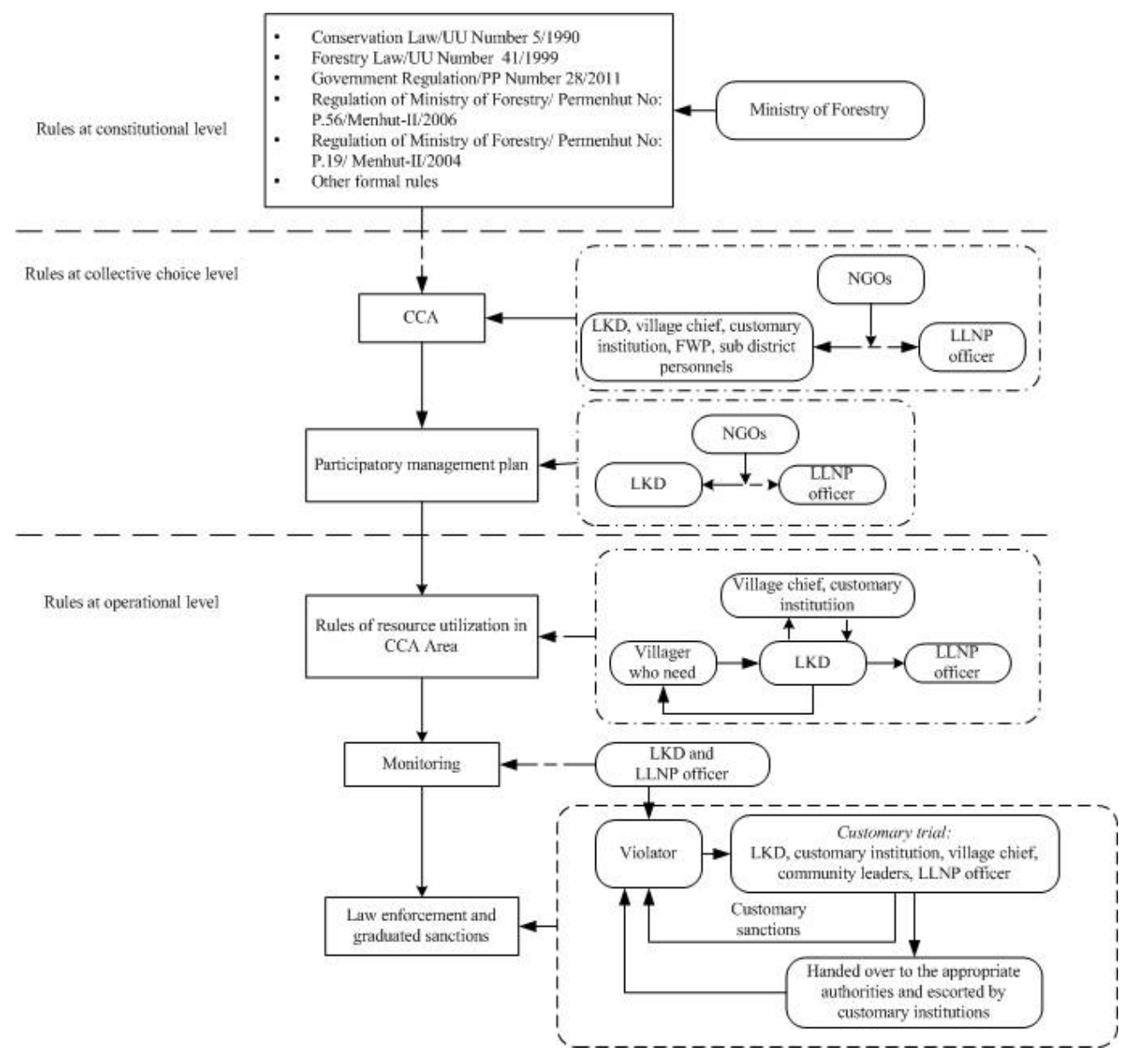

Figure 2 Description of rules designed in CCA.

LLNP Officer about the local communities' request. After that, LKD gives permission to the local community who needs the resources by specifying the number and site of allowing harvested resources.

2 Monitoring rules

Monitoring process arranged in CCA was conducted together with LKD and LLNP Officers/forest rangers. The aim of these rules ware to preserve the resources and to avoid damage (Andersson et al. 2014) and to improve forest condition (Pandey 2010). To avoid forest ecosystem damage in CCA area, the process of monitoring was regularly scheduled every 6 months conducted by LKD and LLNP Officer.

3 Law enforcement and graduated sanction

Appropriators who violate operational rules would be graduated sanction ( giwu) based on indigenous customary law through an open court held by customary institutions and attended by LLNP officer. Graduated sanction aim to hinder participants to conduct a lot of violations of the rules (Cox et al. 2010), because implementation of rules without sanction leads a useless institution (Nugroho 2013). If the case of infringement in the CCA could not be resolved by customary law, then the case of infringement would be handed over to the proper authorities and customary institution should follow the further legal process.

Institutional sustainability barriers of CCA as collaboration management park

1 Problems of structure

Institutional structure affects individual opportunism and participatory. Structure refers to institutional alternatives to order interdependence (Schmid 2004). In this study, structure refers to the rules, property rights and government policies in national park management.

The rules that hamper institutional sustainability of CCA consist of choice rules, position rules, aggregation rules and payoff rules. Description of the types of rules that hamper the sustainability of CCA in LLNP is described in Table 2.

The unclear choice rules were that operational rules of CCA were not in line with formal rules, so that rules arranged at operational level could not be implemented and enforceable because LLNP officer did not recognize several rules at operational level. Local decisions which were not in line with formal rules at the constitutional level consist of rights to withdrawal trees in LLNP area 
Table 2 Identification of CCA rules

\begin{tabular}{|c|c|c|}
\hline Type of rules & Findings & Impacts \\
\hline Boundary rules & $\begin{array}{l}\text { People who want to access and withdraw the } \\
\text { forest resources in CCA area must get approval } \\
\text { from LKD }\end{array}$ & - Clarity of user \\
\hline Choice rules & $\begin{array}{l}\text { - There are rules in the CCA document describing } \\
\text { the types and amount of resources allowed to be } \\
\text { used, but not in line with legal formal rules }\end{array}$ & $\begin{array}{l}\text { LLNP officer did not recognize several rules of } \\
\text { CCA at the operational level }\end{array}$ \\
\hline Scope rules & $\begin{array}{l}\text { - There is a map of CCA area } \\
\text { - There are arrangements of forest resource } \\
\text { utilization location in CCA area }\end{array}$ & - Clarity of resources \\
\hline Position rules & $\begin{array}{l}\text { There are rules that describe the role of the } \\
\text { parties in CCA, but the replacement mechanism } \\
\text { of personnel or leadership in each institution } \\
\text { involved in CCA doesn't ensure the } \\
\text { sustainability of agreements that have been } \\
\text { arranged }\end{array}$ & $\begin{array}{l}\text { Turn of the chairman of customary } \\
\text { institutions and village chiefs, especially in } \\
\text { villages where people were heterogeneous, } \\
\text { lead that the several arranged rules were not } \\
\text { implemented } \\
\text { - Several members of FWP and LKD were } \\
\text { no longer active }\end{array}$ \\
\hline Aggregation rules & $\begin{array}{l}\text { There is no aggregation rules regulating the } \\
\text { stakeholder involvement mechanism in the } \\
\text { management of LLNP } \\
\text { - Legal formal rules of national park management } \\
\text { are command and control and local community } \\
\text { positioned as a user. }\end{array}$ & $\begin{array}{l}\text { - Rules at collective arrangement level have } \\
\text { been not implemented since project ended } \\
\text { - The participatory management plan that } \\
\text { have been arranged didn't implemented }\end{array}$ \\
\hline Information rules & $\begin{array}{l}\text { LKD and LLNP officer/Ranger undertake } \\
\text { monitoring LLNP area. }\end{array}$ & $\begin{array}{l}\text { Forest damage could be prevented as long as } \\
\text { monitoring process was carried out. }\end{array}$ \\
\hline Pay off rules & $\begin{array}{l}\text { There is no rule that regulates clearly the } \\
\text { proportional benefit that would be received by } \\
\text { stakeholders in CCA }\end{array}$ & $\begin{array}{l}\text { FWP and LKD didn't get salary/income based } \\
\text { on their performance }\end{array}$ \\
\hline
\end{tabular}

even if only for local needs and rights to manage continuously their farm that existing in LLNP area. Development of rules on one level, without supporting rules on other levels, would create an unstable system so that cannot be long-enduring (Ostrom 1990). Ting et al. (2012) revealed this situation on community based co management in Baishuijang National Natural Reserve in China, that had a lot of obstacles because most of local decisions made by local committee have resulted in deadlock by management authority due to lack of policy support.

Formal legal rules of national park management in Indonesia at the constitutional level in conservation Law/UU Number 5/1990, Forestry Law/UU Number 41/1999, Government Regulation/PP Number 28/2011, Regulation of Minister of Forestry/P.56/Menhut-II/2006, and Regulation of Minister of Forestry/P.19/MenhutII/2004, tend to be command and control and local communities positioned as the user who only hold access and withdrawal rights. The rule at the constitutional level is a system of rules that determine the form and condition of governance (Carlsson \& Berkes 2005). If CCA intended as collaboration of national parks, the governance system that should be conducted is a merging of government control with local community and decentralization of decision making (Carlsson \& Berkes 2005). However, management rights as collective-choice rights held by the local communities to arrange internal use of forest resource are not described explicitly in legal formal rules. Local communities have weak incentive and responsibility for the preservation of resources if they only hold access and withdrawal rights, without hold collective-choice rights (Agrawal \& Ostrom 2001; Coleman 2011). Strong autonomy of rule-making at local level is the key predictor of better forest to support the livelihood of local people (Singh et al. 2011).

National park management with zoning systems has also become barriers to sustainability of CCA because that rules do not support the sustainability of livelihood of local communities in national parks, especially in rehabilitation zone and utilization zone. In rehabilitation zone areas, local communities preferred to manage continuously the land as farm and in utilization zone areas, local communities preferred to use it forest as a place to take wood for local needs. Meanwhile, formal legal rules of designation of those zones do not accommodate preference and need of local communities. Designation of utilization zone, based on legal formal rules, intends for creating natural ecotourism and recreation, environmental services, education, research that support development of utilization and cultivation activities, and designation of rehabilitation zone intend for restoring damaged ecosystems become or close to the natural ecosystem condition. 
The unclear position rules were that the mechanism of staff changes or replacement of leadership in each institution engaged in the agreement did not guarantee the sustainability of the negotiated agreement, although their tasks and roles described in CCA document. Consequently, some members of FWP, as institution to facilitate resolving conflict between LLNP Officer and villagers or among villagers of the sub district, have no longer served. Moreover, replacements of chairman of customary institution causes rules of CCA have no longer understood by some new chairman of customary institution especially in heterogeneous villages that have many migrants. On the other side, replacement of village chief in some villages with CCA caused the rules of CCA also have no longer understood by the new village chief. Many members of LKD in heterogeneous village have already not activated and replaced by village chief.

Aggregation rules that hamper the institutional sustainability of CCA were not described explicitly the mechanism of aggregation of stakeholders in LLNP management. Formal legal rules of national park management are command and control and local communities positioned as the user who does not hold collective-choice rights. So that, meeting to discuss about CCA was not longer conducted, and local decisions and participatory management plan have not been implemented by local institutions since this project ended.

CCA was designed as a collaborative management (Birner \& Mappatoba 2009), so that it needs to implement symmetric aggregation rules in order that all stakeholders involved in the decision was treated fairly. Collaboration rules of protected area in Indonesia set in Regulation of Minister of Forestry/ P.19/Menhut-II/2004 do not describe technically about the mechanism of involvement of stakeholders in collaborating. According to Wondolleck and Yaffee (2000), collaboration is a process to achieve objectives. However, in Regulation of Minister of Forestry/ P.19/Menhut-II/2004, collaboration is not a process, but as a program of activities that needs to arrange the time in collaboration, as contained in Article $5^{\text {th }}$, Paragraph $2^{\text {nd }} \mathrm{c}$, and Article $9^{\text {th }}$, Paragraph $1^{\text {st }}$ and $2^{\text {nd }}$. Design of pay off rules of CCA did not regulate the appropriate benefit received by stakeholder in the agreement. As a result, LKD as village-level institution that maintain and implement the agreement did not receive salaries or operating budget. Principle of proportional equivalence between benefit and cost is required in the robustness of institution (Ostrom 2005; Krupa et al. 2014).

2 The role of stakeholders and problems of capacity Every actor has a different spectrum capacity (Enserink et al. 2010) both in gaining, controlling, and maintaining access (Ribot \& Peluso 2003). Indigenous people have claimed that LLNP area zoned as CCA was customary land that was proven by the existence of the old cemetery, and bamboo and coffee plants growing in the area before the area was designated as a national park. The land, especially in the rehabilitation zone area, was used by the local communities for farming while in utilization zone area was used by the local communities as site to take timber for local needs such as construction materials, firewood.

The migrants who have settled around LLNP such as ethnic of Buginese and Javanese had high-capacity to gain land in LLNP area. They conducted access mechanism by way of bought the land from indigenous people or work on land claimed by indigenous people with the profit-sharing. High-capacity of access to technology, capital and knowledge of migrants able to gain land resources in LLNP, even though they were not supported by legal rights (Ribot \& Peluso 2003).

LLNP officer had high-capacity of authorities to control access the use of forest resources. However, based on the cause of the area of management and the number of staffs, LLNP officer have not had optimal capacity to control the wide area LLNP. The number of LLNP officers was 13 staffs of forest ecosystem controller and 41 Rangers who control the national park area covering an area 217,991.18 ha (BBTNLL 2014). The wide management area would lead high enforcement cost and imperfect information, so that cause free riders (Rustagi et al. 2010).

Customay institutions, in homogenous villages that had little migrant, had high-capacity to control access of forest use, but in heterogeneous village that had many migrants, customary institutions had the low control capacity of forest use. Customary rules, in villages that had many migrants, could not be able to regulate the use of forest resources. LKD only had high control capacity in the wilderness zone areas because they had high motivation to keep water sources and to avoid disaster, but in the rehabilitation zone area, LKD had the low control capacity and they could not impose sanctions for those who violate the rules of CCA because the land in rehabilitation zone areas had become a farm and de facto the land privately owned. Local communities preferred to manage continuously their farm in rehabilitation zone areas, even though their preference does not support by legal formal rules.

FWP had high-capacity to maintain local community rights on forest resources in LLNP when Central Sulawesi Integrated Area Development Conservation Project (CSIADCP) was running and local government was still supporting funds, facilities and infrastructures. However, their capacity has been low since the project ended and they also did not anymore supported by the local government because of limited funding.

Capacity of NGO that facilitate the process of formulating CCA, such as NGOs Jambata and Karsa, did not have high-capacity to maintain access of the local communities because their programs depend on donors . It was also revealed by Anshari (2006), NGOs as a facilitator in Danau Sentarum National Park had the low technical and financial capacity and their roles often inconsistent because they had to adjust the programs offered by a donor. 


\section{Conclusion}

Institutional sustainability of community conservation agreement designed in LLNP as collaboration management has barriers due to the structure of governance or the main policy of national park management at constitutional level do not support the local communities' rights at the collectivechoice level to regulate the internal use of the CCA forest resource in LLNP. Local decisions which have been arranged could not be implemented due to not in line with constitutional rules of national park management. Arrangement of institution and property rights should consider the capacity of stakeholders in implementing the rules of CCA. Low capacity of local institutions in heterogeneous villages that have many migrants in controlling and regulating the forest use, especially in rehabilitation zone areas, has become a barrier for institutional sustainability of CCA. Therefore, enabling conditions for sustainability of CCA as collaboration of national park management are the change in rules at the constitutional level that accommodate sustainability of livelihoods of local communities, strengthening local institutions' capacity and ultimately integrating institution of CCA as part of LLNP management.

\section{References}

Abdullahi MB, AbdulHameed A. 2012. An overview of local people's livelihood and biodiversity conservation in Maladumba Lake and Forest Reserve (MLFR) Bauchi, Nigeria. Environmental Research Journal 6(3):239-245. http://dx.doi.org/10.3923/erj.2012.239.245.

Acheson JM. 2006. Institutional failure in resource management. Annual Review of Anthropology 35:117-134. http://dx.doi.org/10.1146/annurev. anthro.35.081705.

Adiwibowo S, Shohibuddin, Kartodihardjo H. 2013. Kontestasi devolusi: ekologi politik pengelolaan hutan berbasis masyarakat. In: Kartodihardjo $\mathrm{H}$, editor. Kembali Ke Jalan Lurus. Kritik Penggunaan Ilmu dan Praktek Kehutanan Indonesia. Yogyakarta: Nailil Printika.

Agrawal A, Brown DG, Rao G, Riolo R, Robinson DT, Bommarito IIM. 2013. Interactions between organizations and networks in common-pool resource governance. Environmental Science \& Policy 25:138-146. http://dx.doi.org/10.1016/j.envsci.2012. 08.004 .

Agrawal A, Ostrom E. 2001. Collective action, property rights, and decentralization in resource use in India and Nepal. Politics \& Society 29(4):485-514. http://dx.doi.org/10.1177/0032329201029004002.

Anderies JM, Janssen MA, Ostrom E. 2004. A framework to analyze the robustness of social-ecological systems from an institutional perspective. Ecology and Society 9(1):1-28. http://www.ecologyandsociety.org/vol9/ iss $1 / \operatorname{art} 18 /$.
Andersson K, Benavides JP, León R. 2014. Institutional diversity and local forest governance. Environmental Science \& Policy 36:61-72. http://dx.doi.org/10.1016/ j.envsci.2013.07.009

Anshari GZ. 2006. Dapatkah Pengelolaan Kolaborasi Menyelamatkan Taman Nasional Danau Sentarum? Bogor: CIFOR.

[BBTNLL] Balai Besar Taman Nasional Lore Lindu. 2014. Statistik Taman Nasional Lore Lindu Tahun 2013. Palu: BBTNLL.

Birner R, Mappatoba M. 2009. Co-management of protected areas: A case study from Central Sulawesi, Indonesia. In: Ninan KN, editor. Conserving and Valuing Ecosystem Services and Biodiversity: Economic, Institutional and Social Challenges. United Kingdom: Francis and Tailor.

Carlsson L, Berkes F. 2005. Co-management: concepts and methodological implications. Journal of Environmental Management 75(1):65-76. http://dx.doi.org/10.1016/ j.jenvman.2004.11.00

Dubois O. 1998. Capacity to Manage Role Changes in Forestry: Introducing the '4Rs' Framework. International Institute for Environmental and Development (IIED). http://pubs.iied.org/7537 IIED.html

Coleman E A. 2011. Common property rights, adaptive capacity, and response to forest disturbance. Global Environmental Change 21(3):855-865. http://dx.doi. org/10.1016/j.gloenvcha.2011.03.012.

Cox M, Arnold G, Tomás SV. 2010. A review of design principles for community-based natural resource management. Ecology and Society 15(4):38. http://www.ecologyandsociety.org/vol15/iss4/art38/.

Creswell JW. 2012. Research Design; Pendekatan Kualitatif, Kuantitatif, dan Mixed. Edisi Ketiga. Fawaid A, translator. Yogyakarta: Pustaka Pelajar. Translated from Research Design Qualitative, Quantitative, and Mixed Methods Aproaches. Third Edition.

Ekpe EK. 2012. A Review of economic instruments employed for biodiversity conservation. The Journal of Sustainable Development 12(1):16-32. http://www. consiliencejournal.org.

Enserink B, Hermans L, Kwakkel J, Thissen W, Koppenjan J, Bots P. 2010. Policy analysis of Multi-Actor Systems. The Hague: Lemma.

Ezebilo EE. 2011. Local participation in forest and biodiversity conservation in a Nigerian rain forest. International Journal of Sustainable Development \& World Ecology 18(1):42-47. http://dx.doi.org/10.1080/ 13504509.2011.54438.

Irawan P. 2006. Penelitian Kualitatif dan Kuantitatif untuk Ilmu-ilmu Sosial. Jakarta: DIA FISIPUI. 
Kitamura K, Clapp RA. 2013. Common property protected areas: Community control in forest conservation. Land Use Policy 34:204-212. http://dx.doi.org/10.1016/ j.landusepol.2013.03.008.

Kosmaryandi N, Basuni S, Prasetyo LB, Adiwibowo S. 2012. New idea for national park zoning system: A synthesis between biodiversity conservation and customary community's tradition. Jurnal Manajemen Hutan Tropika 18(2):69-77. http://dx.doi.org/10.7226/ jtfm.18.2.69

Krupa MB, Chapin III FS, Lovecraft AL. 2014. Robustness or resilience? Managing the intersection of ecology and engineering in an urban Alaskan fishery. Ecology and Society 19(2):17. http://dx.doi.org/10.5751/ES-06274190217.

Lambini CK, Nguyen TT. 2014. A comparative analysis of the effects of institutional property rights on forest livelihoods and forest conditions: Evidence from Ghana and Vietnam. Forest Policy and Economics 38:178-190. http://dx.doi.org/10.1016/j.forpol.2013.09.006.

Mehring M, Seeberg-Elverfeldt C, Koch S, Barkmann J, Schwarze S, Stoll-Kleemann S. 2011. Local institutions: Regulation and valuation of forest use-Evidence from Central Sulawesi, Indonesia. Land Use Policy 28(4):736-747. http://dx.doi.org/10.1016/j.landusepol. 2011.01.001.

Nugroho B, Sukardi D, Widyantoro B. 2012. Studi dan Analisis Peraturan Perundangan Terkait dengan Pengelolaan pada Hutan, Hutan Berbasis Karbon, Penyerapan Karbon, Stok Karbon, dan Produk Ramah Lingkungan. Laporan Teknis. Jakarta: Kementerian Kehutanan RI dan ITTO.

Nugroho B. 2013. Reformasi kelembagaan dan tata pemerintahan. Faktor pemungkin menuju tata kelola kehutanan yang baik. In: Kartodihardjo H, editor. Kembali ke Jalan Lurus. Kritik Penggunaan Ilmu dan Praktek Kehutanan Indonesia. Yogyakarta: Nailil Printika.

Nursidah N, Nugroho B, Darusman D, Rusdiana O, Rasyid Y. 2012. Institutional development to build a successful local collective action in forest management from arau watershed unit. Jurnal Manajemen Hutan Tropika 18(1):18-30. http:dx.doi.org/10.7226/jtfm.18.1.18.

Ostrom E. 1990. Governing the Common: The Evolution of
Institution for Collective action. New York: Cambridge University Press. http://dx.doi.org/10.1017/CBO9780 511807763.

Ostrom E. 2005. Understanding Institutional Diversity. United Kingdom: Princeton University Press.

Pandey DN. 2010. Critical necessity of local monitoring and enforcement for sustainable governance of forests. Indian Forester 136(9):1155-1163. http://hdl.handle. net/10535/5090.

Ribot JC, Peluso NL. 2003. A theory of access. Rural Sociology 68(2):153-181. http://dx.doi.org/10.1111/ j.1549-0831.2003.tb00133.x.

Rustagi D, Engel S, Kosfeld M. 2010. Conditional cooperation and costly monitoring explain success in forest commons management. Science 330(6006):961-965. http://dx.doi.org/10.1126/ science. 1193649 .

Schlager E, Ostrom E. 1992. Property-rights regimes and natural resources: A conceptual analysis. Land Economics 68(3):249-262. http://dx.doi.org/ $10.2307 / 3146375$.

Schmid AA. 2004. Conflict and Cooperation; Institutional and Behavioral Economics. United Kingdom: Blackwell Publishing. http://dx.doi.org/10.1002/9780470773833.

Singh VS, Pandey DN, Prakash NP. 2011. What determines the success of joint forest management? Science-based lessons on sustainable governance of forests in India. Resources, Conservation and Recycling 56(1):126-133. http://dx.doi.org/ 10.1016/j.resconrec.2011.09.015.

Soekmadi R. 2003. Pergeseran paradigma pengelolaan kawasan konservasi: Sebuah wacana baru dalam pengelolaan kawasan konservasi. Media Konservasi 3(3):87-93.

Ting Z, Shivakoti GP, Haiyun C, Maddox D. 2012. A surveybased evaluation of community-based co-management of forest resources: a case study of Baishuijiang National Natural Reserve in China. Environment, Development and Sustainability 14(2):197-220. http://dx.doi.org/10. 1007/s10668-011-9316-6.

Wondolleck JM, Yaffee SL. 2000. Making Collaboration Work; Lesson from Innovation in Natural Resources Management. Washington DC: Island Press. 